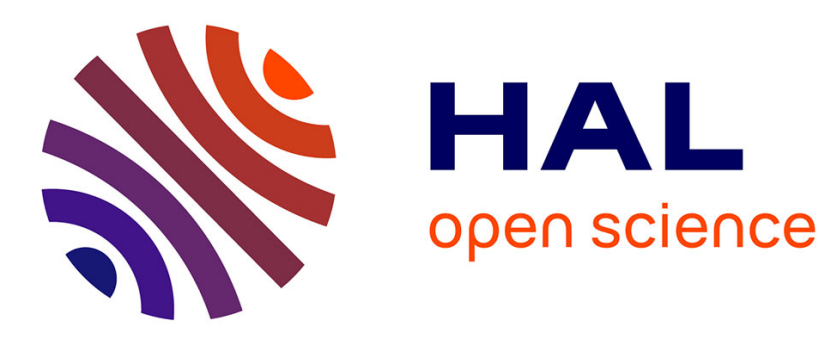

\title{
Acquired factor VIII haemophilia following influenza vaccination
}

Guillaume Moulis, Grégory Pugnet, Haleh Bagheri, Claire Courtellemont, Antoine Huart, Dominique Chauveau, Jacques Pourrat, Jean-Louis

Montastruc

\section{To cite this version:}

Guillaume Moulis, Grégory Pugnet, Haleh Bagheri, Claire Courtellemont, Antoine Huart, et al.. Acquired factor VIII haemophilia following influenza vaccination. European Journal of Clinical Pharmacology, 2010, 66 (10), pp.1069-1070. 10.1007/s00228-010-0852-z . hal-00603640

\section{HAL Id: hal-00603640 https://hal.science/hal-00603640}

Submitted on 27 Jun 2011

HAL is a multi-disciplinary open access archive for the deposit and dissemination of scientific research documents, whether they are published or not. The documents may come from teaching and research institutions in France or abroad, or from public or private research centers.
L'archive ouverte pluridisciplinaire HAL, est destinée au dépôt et à la diffusion de documents scientifiques de niveau recherche, publiés ou non, émanant des établissements d'enseignement et de recherche français ou étrangers, des laboratoires publics ou privés. 


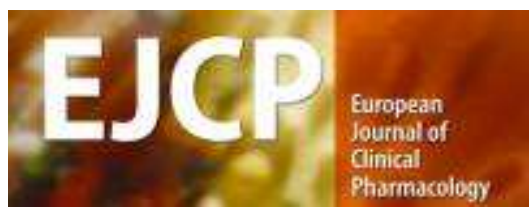

\section{Acquired factor VIII haemophilia following influenza vaccination.}

\begin{tabular}{|r|l|}
\hline Journal: & European Journal of Clinical Pharmacology \\
\hline Manuscript ID: & EJCP-2010-0148.R1 \\
\hline Type of submission: & Letter \\
\hline Date Submitted by the & 27-May-2010 \\
\hline Complete List of Authors: & $\begin{array}{l}\text { Moulis, Guillaume; Faculté de Médecine, Pharmacology } \\
\text { Pugnet, Grégory; CHU Toulouse-Purpan, Université de Toulouse, } \\
\text { Service de Médecine Interne } \\
\text { Bagueri, Haleh; Faculté de Médecine, Université de Toulouse, } \\
\text { Service de Pharmacologie clinique } \\
\text { Courtellemont, Claire; CHU Toulouse-Rangueil, Université de } \\
\text { Toulouse, Service de Néphrologie et Immunopathologie clinique } \\
\text { Huart, Antoine; CHU Toulouse-Rangueil, Université de Toulouse, } \\
\text { Service de Néphrologie et Immunopathologie clinique } \\
\text { Chauveau, Dominique; CHU Toulouse-Rangueil, Université de } \\
\text { Toulouse, Service de Néphrologie et Immunopathologie clinique } \\
\text { Pourrat, Jacques; CHU Toulouse-Rangueil, Université de Toulouse, } \\
\text { Service de Néphrologie et Immunopathologie clinique } \\
\text { Montastruc, Jean-Louis; Faculté de Médecine, Université de } \\
\text { Toulouse, Service de Pharmacologie clinique }\end{array}$ \\
\hline \hline
\end{tabular}

\section{s ScholarONE"


Title: Acquired factor VIII haemophilia following influenza vaccination.

Name, affiliations and adresses of the authors:

Guillaume Moulis ${ }^{1,2}$, Grégory Pugnet ${ }^{1,3}$, Haleh Bagheri ${ }^{2}$, Claire Courtellemont ${ }^{3}$, Antoine Huart ${ }^{3}$, Dominique Chauveau ${ }^{3}$, Jacques Pourrat ${ }^{3}$, Jean-Louis Montastruc ${ }^{1}$.

${ }^{1}$ Service de Médecine Interne, Centre Hospitalier Universitaire de Toulouse, Université de Toulouse, France

Adress: Service de Médecine Interne, salle Le Tallec, CHU Toulouse-Purpan, Place du Docteur Baylac, TSA 40031, 31059 Toulouse cedex, France.

2 Service de Pharmacologie Clinique, Centre Midi-Pyrénées de Pharmacovigilance, de Pharmacoépidémiologie et d'Informations sur le Médicament, Unité de Pharmacoépidémiologie EA 3696, Centre Hospitalier Universitaire de Toulouse, Université de Toulouse, Faculté de Médecine, France Toulouse.

Adress: Service de Pharmacologie Clinique, Faculté de Médecine, 37 Allées Jules-Guesde, 31000

${ }^{3}$ Service de Néphrologie et Immunopathologie Clinique, Centre Hospitalier Universitaire de Toulouse, Université de Toulouse, France

Adress: Service de Néphrologie et Immunologie clinique, CHU Toulouse-Rangueil, Boulevard Ducuing, 31400 Toulouse, France.

\section{Submitting author:}

Guillaume Moulis,

Service de Pharmacologie Clinique,

Faculté de Médecine,

37 Allées Jules-Guesde

31000 Toulouse

Phone: +33561145973

Fax: +33561145642

e-mail: gmoulis@ hotmail.com

\section{Corresponding author:}

Jean-Louis Monatstruc,

Service de Pharmacologie Clinique,

Faculté de Médecine,

37 Allées Jules-Guesde

31000 Toulouse

Phone: +33561145973

Fax: +33 561145642

e-mail: montastruc@cict.fr

Keywords: acquired haemophilia; influenza vaccine 
Autoimmune diseases should occur or be worsened by vaccination due to pharmacological properties of vaccines. We report a case of acquired haemophilia mediated by anti-factor VIII antibody following a vaccination against influenza.

A seventy-two-year-old woman suffered from spontaneous bruises of the wrists at the end of October, 2009. She had been exposed during 31 years (1977-2008) to prednisone for a pulmonary sarcoïdosis. She was also treated by L-thyroxine for Hashimoto's thyroiditis, amlodipine for essential arterial hypertension and paroxetine for depression. The patient was vaccinated against seasonal influenza (MUTAGRIP ${ }^{\circledR}$ ) eight days before the first haemorrhagic symptom. No local complication was noted during the intramuscular injection. She had never been vaccinated by seasonal influenza vaccine before. Clinical examination was normal except the haemorrhagic syndrome. Platelet count was $\mathbf{3 2 0 . 0 0 0 / \mu L}$, activated cephalin time (equivalent to activated partial thromboplastin time) was 72 seconds (indicator: 28 seconds) and prothrombine time $100 \%$. The amount of factor VIII was $1 \%$ and antibody directed against factor VIII was detected at 8 Bethesda units, without any von Willebrand factor deficiency. There was no clinical or biological evidence for any haematopoietic malignancy or systemic disease. Antinuclear antibodies were detected at the limit of significance (title: 1/160), without any specificity (anti-DNA nor anti-extractable nuclear antigens). Symptomatic treatment with activated prothrombin complex concentrates $\left(\mathrm{Feiba}^{\circledR}\right.$ ) was prescribed for 24 hours. Due to ineffectiveness of prednisone (one week at 1 $\mathrm{mg} / \mathrm{kg} / \mathrm{d})$, rituximab was introduced $\left(375 \mathrm{mg} / \mathrm{m}^{2} /\right.$ week, 4 infusions) and clinical and biological remission was observed: after the last infusion of rituximab, factor VIII and its auto-antibody (Bethesda units) were respectively $8 \%$ and 4 three weeks after and $48 \%$ and no detectable four months after.

According to WHO-UMC criteria [1], the score of causality assessment was considered as "possible".

Acquired haemophilia is a very rare disorder due to an anti-factor VIII antibody: its incidence is estimated from 0.2 to 1.9/million/year [2]. An underlying cause is present in approximately half of cases: solid tumours, haematopoietic malignancies, auto-immune diseases, pregnancy and post-partum, infections, drugs (penicillins, sulfa antibiotics, phenytoin, chloramphenicol, methyldopa, interferon- $\alpha$, fludarabine, levodopa, clopidogrel) [3-5]. None of the drugs taken by our patient was known to induce acquired haemophilia. In our knowledge, no post-vaccination acquired haemophilia has been described in the literature for influenza vaccine. The profile of adverse reactions of vaccines against seasonal influenza remains similar to other vaccines and could lead to auto-immune disorders (Guillain-Barré syndrome, encephalomyelitis, idiopathic thrombocytopenic purpura...) [6-7]. Two mechanisms are proposed: 1) an antigenic mimicry, but the delay is usually about several weeks, except in case of previous sensitization; 2) more often, a non specific activation of quiescent auto-reactive $\mathrm{T}$ and $\mathrm{B}$ cells; then, the delay is about several days [6]. This second hypothesis could be suggested for in our observation.

Then, in front of an auto-immune disorder without any known aetiology, a recent vaccination should be searched.

\section{References:}

[1] http://www.who-umc.org/graphics/4409.pdf.

[2] Delgado J, Yimenez-Yuste V, Hernandez-Navarro F, Villar A. Acquired haemophilia: review and metaanalysis focused on therapy and prognosis factors. Br J Haematol 2003;121:21-35.

[3] Franchini M, Targher G, Manzato F, Lippi G. Acquired factor VIII inhibitors in oncohematology: a systematic review. Crit Rev Oncol Hematol 2008;66:194-9.

[4] Franchini M, Capra F, Nicolini N, Veneri D, Manzato F, Baudo F, Lippi G. Drug-induced anti-factor VIII antibodies: a systematic review. Med Sci Monit 2007;13:RA55-61.

[5] Franchini M, Lippi G. Acquired factor VIII inhibitors. Blood;112:250-5.

[6] Wraith D, Goldman M, Lambert PH. Vaccination and autoimmune disease: what is the evidence? Lancet 2003:62:1659-66.

[7] Agmon-Levin N, Kivity S, Shoenfeld Y. Influenza vaccine and autoimmunity. IMAJ 2009;11:183-5. 
Autoimmune diseases should occur or be worsened by vaccination due to pharmacological properties of vaccines. We report a case of acquired haemophilia mediated by anti-factor VIII antibody following a vaccination against influenza.

A seventy-two-year-old woman suffered from spontaneous bruises of the wrists at the end of October, 2009. She had been exposed during 31 years (1977-2008) to prednisone for a pulmonary sarcoïdosis. She was also treated by L-thyroxine for Hashimoto's thyroiditis, amlodipine for essential arterial hypertension and paroxetine for depression. The patient was vaccinated against seasonal influenza (MUTAGRIP ${ }^{\circledR}$ ) eight days before the first haemorrhagic symptom. No local complication was noted during the intramuscular injection. She had never been vaccinated by seasonal influenza vaccine before. Clinical examination was normal except the haemorrhagic syndrome. Platelet count was $320.000 / \mu \mathrm{L}$, activated cephalin time (equivalent to activated partial thromboplastin time) was 72 seconds (indicator: 28 seconds) and prothrombine time $100 \%$. The amount of factor VIII was $1 \%$ and antibody directed against factor VIII was detected at 8 Bethesda units, without any von Willebrand factor deficiency. There was no clinical or biological evidence for any haematopoietic malignancy or systemic disease. Antinuclear antibodies were detected at the limit of significance (title: 1/160), without any specificity (anti-DNA nor anti-extractable nuclear antigens). Symptomatic treatment with activated prothrombin complex concentrates $\left(\mathrm{Feiba}^{\circledR}\right.$ ) was prescribed for 24 hours. Due to ineffectiveness of prednisone (one week at 1 $\mathrm{mg} / \mathrm{kg} / \mathrm{d}$ ), rituximab was introduced ( $375 \mathrm{mg} / \mathrm{m}^{2} /$ week, 4 infusions) and clinical and biological remission was observed: after the last infusion of rituximab, factor VIII and its auto-antibody (Bethesda units) were respectively $8 \%$ and 4 three weeks after and $48 \%$ and no detectable four months after.

According to WHO-UMC criteria [1], the score of causality assessment was considered as "possible".

Acquired haemophilia is a very rare disorder due to an anti-factor VIII antibody: its incidence is estimated from 0.2 to $1.9 /$ million/year [2]. An underlying cause is present in approximately half of cases: solid tumours, haematopoietic malignancies, auto-immune diseases, pregnancy and post-partum, infections, drugs (penicillins, sulfa antibiotics, phenytoin, chloramphenicol, methyldopa, interferon- $\alpha$, fludarabine, levodopa, clopidogrel) [3-5]. None of the drugs taken by our patient was known to induce acquired haemophilia. In our knowledge, no post-vaccination acquired haemophilia has been described in the literature for influenza vaccine. The profile of adverse reactions of vaccines against seasonal influenza remains similar to other vaccines and could lead to auto-immune disorders (Guillain-Barré syndrome, encephalomyelitis, idiopathic thrombocytopenic purpura...) [6-7]. Two mechanisms are proposed: 1) an antigenic mimicry, but the delay is usually about several weeks, except in case of previous sensitization; 2) more often, a non specific activation of quiescent autoreactive $\mathrm{T}$ and $\mathrm{B}$ cells; then, the delay is about several days [6]. This second hypothesis could be suggested for in our observation. searched.

Then, in front of an auto-immune disorder without any known aetiology, a recent vaccination should be

\section{References:}

[1] http://www.who-umc.org/graphics/4409.pdf.

[2] Delgado J, Yimenez-Yuste V, Hernandez-Navarro F, Villar A. Acquired haemophilia: review and metaanalysis focused on therapy and prognosis factors. Br J Haematol 2003;121:21-35.

[3] Franchini M, Targher G, Manzato F, Lippi G. Acquired factor VIII inhibitors in oncohematology: a systematic review. Crit Rev Oncol Hematol 2008;66:194-9.

[4] Franchini M, Capra F, Nicolini N, Veneri D, Manzato F, Baudo F, Lippi G. Drug-induced anti-factor VIII antibodies: a systematic review. Med Sci Monit 2007;13:RA55-61.

[5] Franchini M, Lippi G. Acquired factor VIII inhibitors. Blood;112:250-5.

[6] Wraith D, Goldman M, Lambert PH. Vaccination and autoimmune disease: what is the evidence? Lancet 2003:62:1659-66.

[7] Agmon-Levin N, Kivity S, Shoenfeld Y. Influenza vaccine and autoimmunity. IMAJ 2009;11:183-5. 